\title{
Nested comparisons: nation-building through comparative thinking about Albanian law
}

\author{
Eleanor Pritchard"
}

\begin{abstract}
Since the late nineteenth century, ideas about law, both Albanian and 'other', have played significant parts in the development of a sense of 'Albanian-ness' and remain central to the ongoing construction of the nation. In this paper, I examine how comparative thinking about 'Albanian law' in northern Albania and predominantly Albanian Kosovo has contributed to nation-building aims, with particular reference to comparative thinking around the Kanun of Lekë Dukagjin, an earlytwentieth-century legal code rooted in northern-Albanian customary practices. I look at this from two perspectives: comparative thinking by the law-writer in the Kanun and comparative thinking by a contemporaneous writer about the Kanun. Through these perspectives, we gain a more nuanced understanding of the intellectual context of the Kanun's production than is reflected in the existing literature, and a glimpse of its continued relevance today to ideas of nation.
\end{abstract}

\section{Introduction}

Since the late nineteenth century, Albanian understandings of their historical law have featured prominently in discussions of nation. In this paper, I tease out some of the late nineteenth and early twentieth-century comparative thinking about 'law', which continues to carry influence today, including that by contemporary Albanian nation-builders and comparisons made by external commentators, to which the nation-builders responded. Also, I show some of the scholarly comparisons that can be made with the Albanian case, to develop broader points. The reference to 'nested' in the title is a reminder that these different types of comparison are not made in a vacuum, but often in awareness of other comparisons. The paper begins with an extended introduction, which links conceptual and empirical elements, discusses the empirical material and concludes with an overview of the relevance of the Kanun of Lekë Dukagjin (hereafter 'the Kanun') in contemporary society.

The Albanian people live in the Balkan Peninsula of south-eastern Europe; today, the population numbers around seven million. They are a non-Slavic people, whose language is Indo-European, but unrelated to the other members of the family. Albanians understand themselves to be descended from the Illyrians, a pre-Roman people and, thus, the oldest inhabitant population of the Balkans.

From the middle of the fifteenth century, the Albanians lived in the Ottoman Empire, which was divided by the borders of administrative districts and had a governance structure based on religious communities. These were geographically dispersed across districts, without a common, unifying religion. By the mid-nineteenth century, the majority of Albanians were Muslim, but there were also significant proportions of Roman Catholics (mostly in northern Albania) and Greek Orthodox (mostly in the south). In the late nineteenth century, driven by the publications of the Catholic monks in the northern city of Shkodra, a sense of Albanian nationhood began to emerge within Albania. In the early twentieth century, one of these monks, the Franciscan Fr Shtjefën Gjeçov,

* Centre for Socio-Legal Studies, University of Oxford, Manor Road Building, Manor Road, Oxford, OXI 3UQ, UK. E-mail: eleanor.pritchard@csls.ox.ac.uk. 
produced the Kanun of Lekë Dukagjin, rooted in the customary practices of northern Albania. It is a text containing rules, descriptions and definitions pertaining to the lives of northern-Albanian Catholics living in the mountainous Mirdita region. It is structured as a I35-page legal code, with themed sections and numbered provisions within each section, and is written in the vernacular language of the Mirdita region of northern Albania.

Following the disintegration of the Ottoman Empire and the subsequent creation, in I9I 2, of the Republic of Albania, around half the Albanian people were left outside the borders of the new state, in neighbouring territories that, today, belong to Kosovo, Montenegro, Serbia and Greece. Over the course of the twentieth century, Kosovo was part of the Kingdom of Yugoslavia (I9I8-1939) and then, after World War II, Socialist Federal Yugoslavia. In I998-I999, there was a war between the ethnic-Albania Kosovo Liberation Army and Serbian military and paramilitary forces; this ended with Kosovo being made an international protectorate with 'supervised independence'. In 2010, having met various benchmarks, EULEX, the supervising EU Rule of Law mission in Kosovo, declared an end to supervised independence. Today, Kosovo is in the process of harmonising its legal system with EU requirements, with a view to future EU accession. Thus, questions of collective identity remain as pertinent to contemporary Kosovar Albanians as they were to the early twentieth-century nation-builders; the experiences of the twentieth century have only strengthened popular perceptions of the links between law and national identity.

The anthropologist David Parkin suggested that ' $[t]$ he human drive to compare is really the search for continuity in phenomena' (Parkin, I987, p. 66). Scholars undertaking empirical work on sociolegal matters may encounter informants who are themselves thinking comparatively, particularly when they are involved in their own interpretivist projects (Greenhouse, I988, p. 688), such as the conscious construction or preservation of a community. ${ }^{\mathrm{I}}$ This may be in conversation with us, as outsiders, to help us understand the phenomenon or situation they are trying to explain - the unfamiliar ' $x$ ' is like the familiar ' $y$ ' - or it may be between themselves. This paper is concerned with the latter: by taking comparative thinking as a source of information in itself, we can ask why it is taking place, who is the intended audience and how it contributes to local understanding(s) of the socio-legal matter(s) under discussion. We can then take a step back, and consider whether and how this enriches our understanding(s) of the socio-legal matter(s) in question. In this paper, I adopt this approach to shed light on how ideas of Albanian law have shaped and reflected understandings of the nation.

\section{Historical sketch}

From the late fourteenth century, the historically Christian Balkans were part of the Islamic Ottoman Empire and large sections of the population(s) converted to Islam. The law of the Empire was the Islamic şeriat, supplemented by Sultanic law; this applied to all Muslims and, for any case involving a Muslim, took precedence over any other 'legal' system. ${ }^{2}$ However, the legal structure of the Ottoman Empire allowed the existence of religious communities (millets), which had considerable autonomy over internal matters and the maintenance of order (Karpat, I982; Skendi, I982), and considerable self-governance by border tribesmen (Köksal, 2006; Kasaba, 2008). Under

I In producing his eponymous Law Code (begun in II84), the Armenian monk Mxit'ar Goš, for example, reacted to the negative perceptions he understood the Muslim rulers to have of the Armenian people, in consequence of their 'not having law' (Thomson, 2000), while (contrary to Watson's analysis) Armenian lawyers working on their draft Civil Code in April I997 argued strenuously that it was heavily influenced by Roman, rather than Russian, law (Watson, I998).

2 Şeriat is the Ottoman Turkish spelling of the Arabic, usually rendered in English as shari'a. It is given here and throughout in the Ottoman Turkish spelling, to emphasise what the nation-building Catholic Albanians saw as its 'foreignness'. 
these conditions, in which local 'legal' systems could exist and operate among non-Muslim populations, this created local 'legal' communities, such as in the northern-Albanian highlands, where Catholic Albanians used customary practices to maintain order within their communities, through councils of elders who settled disputes and administered local justice. This structure allowed the Empire to maintain indirect control over vast territory, which would have been difficult to subdue militarily, and to create tribal borderlands at the edges of the Empire to deter invasion. For non-Muslims, a further consequence of the millet structure was to shape senses of non-Muslim collective identity along religious, rather than national, lines. In some cases, these different ways of conceptualising belonging happened to align - membership of the Serbian Orthodox Church was a core marker of Serbian-ness - but not so for the Albanians. ${ }^{3}$

Following the Ottoman arrival in the region, some Albanians began to convert to Islam, adding a Muslim Albanian population to the existing Albanian Christian Orthodox and Roman Catholic populations. By the mid-nineteenth century, the majority of the Albanian population was Muslim, but there remained a significant Catholic population in the northern-Albanian highlands. By the late nineteenth century, different perspectives on the legal-political future of the Albanians were apparent. In 1878, the powerful Muslim Albanian landowners, predominantly in Kosovo, explicitly committed to a future within the Empire and to maintaining the şeriat, although they sought a greater degree of autonomy than they had previously enjoyed. ${ }^{4}$ In contrast, the Roman Catholic nation-building elite in the north had protected status under the Austro-Hungarian kulturesprotektorat (established in the seventeenth century as part of a peace settlement after an Ottoman-Austro-Hungarian war), which allowed them to print educational materials in Albanian, and a strong interest in an independent future outside the Ottoman Empire. This range of perspectives is understandable given that, among those I am retrospectively calling 'the Albanians', there was a shared oral Albanian language, but no shared sense of what it meant to be 'an Albanian': the population was fragmented by religion, scripts and the lack of a written language. This was the context into which the Albanian 'national awakening' (Rilindja) movement emerged among the Christian and Sufi Albanians in the mid- to late nineteenth century. It was strongly influenced by ideas about nation and state, which had originated in Germanic countries (see below), and moved downwards through central Europe. In terms of Albanian 'law' in this period, commentary from Ottoman officials and early travellers shows us that Albanian-speakers in the north had a sense of 'our law' before there was a written legal code, which they often called 'The Kanun of Lekë', or 'The Law of Lekë' (e.g. Midhat Bey, I903; Durham, I909 [2000]; I928). These early commentators often touched on this Albanian 'law' in a comparative sense: Ottoman officials presented it as flawed and inadequate in explicit comparison with the şeriat, while Western-European travellers looked at it in a historical comparative sense, seeing it as a 'primitive' means of maintaining order (e.g. Knight, I880)..$^{5}$ Although there is no evidence to suggest a direct response by the Albanian nation-builders to these examples of external comparison, we know from 'foreign' papers about, or which touched on, 'the Albania question' reprinted in contemporary Albanian periodicals that the Albanians were alert to external perceptions of their nation and politics. Given the dependence on the Great Powers for recognition of the new state,

3 When I use 'Albanians' to describe people before the nineteenth century, it is shorthand for 'Albanianspeakers' and is a pragmatic simplification of the way in which individuals might have identified themselves. For an example of the difficulty a nineteenth-century intellectual had in explaining the concept of 'being Albanian' to an Albanian, see 'The Albanian Nation', in Albania (I897/I I, p. Ar8I).

4 This is stated explicitly in the Kararname (Resolutions) of the I878 League of Prizren; see Robert Elsie's translation, available at: 〈http://www.albanianhistory.net/textsi9_2/AHi878_2.html〉.

5 For examples of the Ottoman perspective on the Kanun, see the Ottoman Government Yearbook of the Vilayet of Kosova I896-I897, and those of the Vilayet of Manastir I889-I890 and the Vilayet of Shkodra I982-I993. 
this is not surprising and was a preoccupation shared by nation-builders in Kosovo in the late I99os and early 2000s, who also needed to secure external recognition of the new state.

In summary, at the time of the Kanun's codification, the nation-builders were looking for evidence, rooted in the Albanian language, of a distinct culture, so as to make and bolster the claim of an Albanian nation. The more 'untouched' this evidence was by the Ottoman occupation, the greater was its authenticity and legitimacy. This quest led them to scouring the Catholic northern-Albanian highlands for material (see e.g. the periodical Hylli i Dritës, 1913-1944) and, eventually, to the publication of the Kanun.

\section{III. 'Albanian', 'nation' and 'Kanun'}

\section{1 'Albanian'}

The settlement of the Albanian borders at the London Conference of I9I2, which created the country of Albania, left half the Albanian-speaking population of the Balkans outside the borders of the new state. Thus, although often treated as unproblematic, the English term 'Albanian' can signify both nationality (discussed below) and, after I9I2, a citizen of Albania; here I use it in the sense of 'nationality', which also is not straightforward. Broadly, the Albanian population of the Balkans is divided into Geg (in the north) and Tosk (in the south); this is more than a geographical divide, as it also describes different dialects, forms of cultural expression and historical forms of social organisation. Thus, in considering the place of law in nation-building, we should be aware that, in addition to the religious divides outlined above, the target population was not historically, culturally or socially homogenous.

\section{2 'Nation' and 'nation-building'}

The idea of 'nation' (kóm or komb in Albanian), which emerged in late-eighteenth-century Western Europe, came later to the Albanians; it reached the literate elite around the last quarter of the nineteenth century and the illiterate masses after that.

The Rilindja movement conceived of the Albanian nation as bound by the 'primordial ties' of birth, language, dialect and social practices (Geertz, I963, p. I09). ${ }^{6}$ Smith has described this as an 'ethnic' model of nation for which 'a nation was first and foremost a community of common descent' (Smith, I99I, p. II). The nation-builders were largely intellectuals with special access to 'culture values' who became leaders of a 'culture community' (Weber, I948, p. I76). They were heavily influenced by Romantic Germanic eighteenth- and nineteenth-century ideas, and in particular those of J.G. von Herder (I744-1803). Herder saw a nation as an organic entity, and believed that 'that which people who belong to the same group have in common is more directly responsible for their being as they are than that which they have in common with others in other places' (Berlin, I999, p. 6I). He understood nationality to be a cultural attribute, which can and should be defended (Berlin, 2000, p. 27), and 'delighted' in everything which could be seen as natural and different, believing in a society in which 'men, whoever they are, can live full lives [and] attain free self-expression' (Berlin, 2000, p. 206). In this context, the Kanun can be regarded as a nation-building project in the sense of an action undertaken with the intent of increasing the number of men recognising themselves, and one another, as belonging (Gellner, I983, p. 7). It was also intended to strengthen a sense of 'Albanian-ness'.

The nation-builders of central and Eastern Europe used the folk cultures of their own people as sources and inspiration for their literature, art and music. However, there appears to be no evidence of

6 In this, the Albanian nation had much in common with other central, east and south-east European nations including the Serb (Judah, I997), Croat (Uzelac, 2010), Czech (Williams, I997, p. I35), Slovak (Brock, 1976) and Hungarian (Schöpflin, 2000). 
the contemporaneous 'intellectuals' of other regional nations generating 'law' comparable to the Kanun, based on their own nations' customary practices.7 In the case of the Kanun, this highlights the significance of the legal form: while the builders of other nations (and, indeed, other Albanian nation-builders) may have used substantially similar source material, and described a normative order and rules in their writings, they did not present that material in the form of a legal code. ${ }^{8}$

\section{3 'The Kanun'}

Fr Shtjefën Gjeçov, author of the Kanun, spent much of his working life as a parish priest in the Catholic highlands. He was a nation-builder in the nineteenth-century mould, drawing on ideas of thinkers such as Herder and Savigny. His body of work is influenced by Germanic ideas of the volk, the importance of language as a determinant of nationality and the 'natural' political state of a volk as being one of self-determination (Gjeçov, I985). These ideas underpinned the development of the concept of nation among northern-Albanian Catholics, which was based on the idea of an extended tribe ( $f i s) .{ }^{9}$ Gjeçov worked to record the existence of his people during a period when, for the first time, it must have looked as if a legal and political future outside the Ottoman Empire was possible.

There is no earlier comprehensive code in Albanian that might be taken as the ancestor of the Kanun, although some (including Gjergj Fishta, below) have argued the existence of historical written code that was lost. Gjeçov's text was rooted in northern-Albanian customary practices, and was first published serially between I9I3 and I925. ${ }^{\text {IO }}$ It was, but was not only, a recording of customs practised by the Catholic northern Albanians living in the mountainous Mirdita region; it also offered definitions of categories and concepts in northern-Albanian society, which Honoré has argued is an often overlooked function of 'real laws' (1977, p. 108), and described relationships between categories and concepts, both of which could have underpinned the development of Albanian legalistic thinking. It was written in the dialect of the Mirdita region, which would have placed its authenticity further beyond reproach for the nation-builders. Its content expressed what the nation had been and was - a distinct and self-governing community - and it is laced with around roo notes that refer to legal texts (from Roman, Hindu and biblical law) and non-legal texts that address the idea of a legal community, including philosophical tracts, histories and commentaries.

In both the text of the Kanun and its Foreword, we can trace Enlightenment and Romantic philosophical themes, as well as jurisprudential ideas of the German Historical School, founded by the jurist and historian Savigny (I779-I86I), who applied to law Herderian ideas of nation (Berlin, 2000, p. I70, f/n I). The Historical School emerged as a reaction against ideas of both natural law and analytical positivism, and presented law as a product of customs and practices in particular communities, embedded in - rather than imposed upon - society, necessarily accepted and observed by that society, holding authority by benefit of tested and proved tradition (to use Weber's terminology) and fundamentally derived from custom. Savigny understood law to be as

7 For example, the German linguists and folklorists, Jacob and Wilhelm Grimm (I785-I863 and I786-I859), collected and published German folk stories while, in Denmark, Hans Christian Anderson (I805-I875) wrote 'new' folk stories. In the Balkans, the nineteenth-century Serbian scholar-poet, Vuk Karadžić (I787I864), collected folk stories, songs and riddles, including 'Serbian National Proverbs' (I900), and the Montenegrin Prince-Bishop Njegoš composed an epic in the mixed form of poetry and a play, 'The Mountain Wreath' (I846), about Montenegrin resistance to Ottoman occupation (Njegosh, I930).

8 For example, Brkićs analysis of justice, injustice and vengeance in traditional Serbian epic poetry (I96I, pp. I38-I53) draws on material collected by Vuk Karadžić.

9 I use 'tribe' as a non-pejorative translation of fis.

Io For simplicity, all references here are given to the English-language version of the bilingual edition of the Kanun (Gjeçov, I989 [I933]). 
fundamental a marker of nation as language: 'in the earliest times to which authentic history extends, the law will be found to already have attained a fixed character, peculiar to the people, like their language, manners and constitution' (I8I4 [I999], p. 17). Savigny was broadly opposed to codification and there is a tension between this position and the work of Gjeçov and Fishta: while implicitly endorsing a Herderian understanding of nation and a Savignian view of law, they also prized codification, in the Albanian case, for its potential benefits to the legal-political community. The Historical School contained two strands of thought: Romanists, of whom Savigny was one, held that the Institutes of Justinian (from the sixth century) could be applied in the nineteenth-century context 'without regard to the thirteen intervening centuries' (Leonard, I907, p. 580), while the Germanists 'reconstructed' and endorsed old German law untouched by Roman thought, thus leaping from the twelfth century to the nineteenth. To a modern scholar, both positions may appear simplistic but, to nation-building Albanians in the late nineteenth and early twentieth centuries, both strands had their appeal. In the Kanun, we can see sympathy for both the Romanist and Germanist views, albeit in the Foreword apparently set on foundations of broadly Enlightenment understandings about the perfectibility of man and society. When we remember that these texts were not produced by philosophical or legal scholars, but rather for specific and practical purposes of nation-building, this blend of influences is unsurprising. The texts suggest that the authors were broadly aware of contemporaneous schools of thought and, from these, made use of those elements that best supported their views.

As the Albanian 'nation' had no history of centralised self-government prior to the founding of the Albanian state in I9I2, the Kanun was not 'law' in the sense of legislation promulgated by a ruler or legislature and, as such, does not satisfy the link Roberts proposed between 'the cultural assemblage we have come to call law [and] attempts to "govern"' (Roberts, 2005, p. 13) or illustrate what Schwartz called 'a public monopoly of force' (Schwartz, I955, p. 569). Roberts made his arguments in the context of an appeal to draw back from what he saw as an increasing tendency to see law 'as somehow "everywhere" in the social world, present even in the simplest aggregations' (Schwartz, I955, p. 2) but, while it is well to be cautious in the use of the term, for fear of its losing any substantial meaning, there are many examples of 'law' that are not linked to governance, including the twelfth-century law code of the Armenian monk, Mxit’ar Goš (Thomson, 2000), the legal texts of the Barbarian Kings (Wormald, I999) and a massive bibliography of texts on Hebrew law produced in Mandate Palestine (Likhovski, 2006). The text of the Kanun was not used as a tool of governance but, as these examples illustrate, legal codes can have significance, purposes and uses beyond straightforward implementation (Pirie, 2010). Analytically, the Kanun can be seen as a legalistic exercise, the intended and actual significance of which lay in its use of the Albanian language and its explicit definitions of rules, categories and exemplary cases.

\section{Comparative thinking in the text of the Kanun}

The text is full of notes, the majority of which are Latin-language references to other texts and a small number of which are in Italian or Albanian. As most of the population of the area in which Gjeçov collated and codified the Kanun was illiterate - an editorial in the Zëri i Popullit newspaper gave an illiteracy rate of 93 per cent as late as the end of World War II (Pipa, I978, p. 87) - these notes could not have been part of the ethnographic material collected by Gjeçov, but must have been added by him, and would have shown a well-read and sympathetic clerical readership that scholarly work could be done on Albanian topics, in the Albanian language. The notes have made an impression on some scholars, including the Albanian social scientist Tarifa (2008) and the translator Fox, who takes the notes to indicate direct correlation with the cited texts and thus possible textual ancestry for the Kanun (Fox, I989, p. xvi). However, Gjeçov himself drew no 
conclusions from his references and, in the absence of a commentary, the reader can only understand these notes as points of comparison; they are of little, if any, functional benefit to the text as a legal code. At a level of generality, we can say that, in the breadth of his comparisons, it looks as though Gjeçov not only sought evidence in other times and societies of practices and principles similar to those of the Albanians, but also thought about the nature of law and legal authority.

As an Albanian nation-builder, wishing to demonstrate that the Albanians were a distinct and coherent people, Gjeçov would have been aware of the different ideas of law and legal traditions, which had developed from Western-European Christianity on the one hand and Islam and the Ottoman Empire on the other. A third of the notes are direct references are to legal texts: Roman Law, the biblical Pentateuch and, perhaps more surprisingly, the Laws of Manu (compiled between $200 \mathrm{BC}$ and $\mathrm{AD} 200$ and, according to Hindu tradition, a record of the words of Brahma, one of the Gods of creation (Olivelle, 2006)). Twelve refer to Roman Law, specifically the Twelve Tables, the Institutes of Gaius and Ulpianus, and the Corpus Juris Civilis. Thus, Gjeçov located his code in the context of earlier legal codes and, at a symbolic level, the references to Roman Law lent his Kanun the authority of that august legal tradition. Just over one-tenth of the references in the notes are to Old Testament passages and, with only two exceptions, are to passages of books in the Pentateuch or the 'law books' of the Bible (Ryle, I909). In addition to the direct connection this draws between legal systems, it is probably also relevant that the books of the Pentateuch are accepted by all Christian traditions, and are also recognised by Muslims and Jews as key religious texts. This suggests that, in his comparative thinking and, more broadly, in his nation-building, Gjeçov was looking for evidence of common ground among Albanians.

The absence of some texts - and thus legal traditions - in Gjeçov's notes is also interesting; in particular any references to the şeriat or Ottoman Sultanic law. The Mirdita, from whence the text emanated, was (and remains) a predominantly Catholic region, to which the Ottoman administrative structure allowed considerable self-governance. While Sultanic law and the şeriat may not have featured in the day-to-day lives of the region's inhabitants, trade would have been subject to Ottoman law, which is not mentioned at all. In his analysis of comparison and continuity, Parkin reminds us that 'the sense of comparability comes from what is absent as much as present' (Parkin, I987, p. 62): by omission, Gjeçov wrote Ottoman and, by extension, Islamic influences out of the Kanun and thus, in the Catholic northern-Albanian narrative, the Ottomans are denied any historical responsibility, or credit, for order.

\subsection{Links to nation-building narratives}

Given the political climate of the time, and Gjeçov's known nation-building ideals, there are at least three contemporaneous national narratives to which his comparative thinking in the notes could have contributed.

Although the majority of the Albanians of the Balkans were Muslim at the time of Gjeçov's codification, there was a narrative thread in Albanian nation-building that held that Albanians were 'naturally' Catholic and that conversions to Islam had taken place under duress and were somehow 'inauthentic'. ${ }^{I}$ We can see this thread in the stories of the medieval Albanian prince and Ottoman janissary, Skanderbeg (I405-I468), for example, which tell of a Catholic-Albanian boy taken by the Ottomans under the devşirme system and converted to Islam, then, driven by his 'natural' faith and national loyalties (Barleti, I596; Hodgkinson, 2004), returned to northern Albania to fight with the Catholic Albanians against the Ottoman Empire. The absence of any reference to Islam, Islamic law or the Sultanic law of the Muslim head of the Ottoman Empire, in

I I This is a theme common in the historiographies of Balkan peoples: e.g. Marina Todorova has noted in the work of the Bulgarian Ottomanist Strashimir Dimitrov, the "implicit conclusion ... that the Ottoman authorities were creating economic and social incentives for conversion' (Todorova, 2004, p. I45). 
a text presented as an 'authentic' Albanian legal code, would have spoken to this debate, as demonstration that, in the words of the expatriate Constantin Chekrezi: 'The despised Turk has been utterly incapable of exercising any kind of influence on [Albanian] national characteristics, language, customs, traditions' (Chekrezi, I9I9, p. I0). Such perceptions of a 'natural' connection between Albanians and Christianity would have been strengthened by the frequent references in the notes to the Bible.

The second narrative was the antiquity of the Albanian people and, specifically, their claim to be the autochthonous people of the region - an example of what, in his taxonomy of myths, Schöpflin described as a 'myth of ethnogenesis and antiquity' (Schöpflin, I997, p. 34). ${ }^{12}$ A reader aware of the publication dates of the texts referred to in the notes might draw the conclusion that the (undated) Albanian 'law' presented in the Kanun was of similar antiquity. The claim of autochthony was of particular importance to the Albanian nation-builders because it gave them a connection to the land that predated the arrival of the Slavs and Ottomans.

The third narrative was that of national genealogy. The early nation-builders were concerned to demonstrate the national genealogy of the Albanian people, drawing connections variously with the Illyrians, Dardanians and Pelasgians. One thread of non-European genealogy was even proposed around a Caucasian line of descent, linked to an area in the Caucasus known as 'Albania' (Malcolm, I998, p. 74). This might account for the otherwise puzzling references to the Law of Manu, even if these only demonstrated points of correspondence between Albanian custom and an ancient and non-European legal code.

In addition, the contribution to the developing Albanian language 'graphosphere' (Franklin, 20II) should not be underestimated. ${ }^{\mathrm{I} 3}$ Before $\mathrm{I} 908$, there was no common script for the Albanian language and its speakers wrote in the script of their religion (Catholics in Latin, Orthodox in Greek and Muslims in Ottoman). ${ }^{\mathrm{I}}$ Except under the limited terms of the kulturesprotektorat, Ottoman laws had specifically prohibited education and publications in the Albanian language, so the Albanian written world had remained extremely limited and largely based outside the country. In such an environment, the galvanising impact on the nation-builders of a document as lengthy and as prestigious as a legal code can only be imagined.

Gjeçov arranged his Kanun as a legal code, an aspirational form, which suggested what the nation could be: a people with a legal code, and a viable, functioning and authentically 'national' alternative to şeriat and Sultanic law. There was also a directly functional dimension to Gjeçov's work: his codification is an example of Bohannan's 'double institutionalisation' - that is, the restatement of some customs for the 'more precise purposes of [anticipated] legal institutions' (Bohannan, I957, p. 36). Through codification, Gjeçov moved the knowledge about the Albanian way of 'doing law' from practice to text, and from village to town; he and his colleagues seem to have hoped that the Kanun had the potential to be a foundational legal document for the nascent Albanian state. While, in practice, his efforts were overtaken by politics, some of the ideas his work contained took deep root. To Gjeçov's peers, his Kanun would have been evidence of a complex, indigenous, self-governing culture in northern Albania, which demonstrated sufficient difference between the Albanians and surrounding peoples to meet the Romantic criteria for a 'nation'.

I2 For an exposition of this narrative, see Effendi (I879 [I999]), in particular p. 22.

I3 Franklin defines a 'graphosphere' as the social and cultural spaces in which language messages and information in a particular language are recorded, stored, displayed and disseminated (Franklin, 20I I, p. 53I).

I4 The Latin script and an alphabetic variant based on the 'Istanbul' and 'Bashkimi' variants were agreed at the Congress of Manastir in I 908, giving Albanian a standard written form for the first time. These choices were unpopular with conservative Muslim Albanians, who saw the Latin script as an infidel script but, despite their strong resistance, it took hold. 


\section{Comparative thinking about the text of the Kanun}

Fr Gjergj Fishta, one of Gjeçov's closest colleagues, wrote an extended Foreword to the single-volume edition of the text, which was published in 1933, twenty years after Albania declared independence and four years after Gjeçov's death. ${ }^{15}$ By the early I930s, although the new Albanian state had been established, it was in its turbulent infancy, characterised by a high turn-over of governments, lack of functional cohesion and tensions between pre-existing tribal power structures and newly minted state institutions and hierarchies. Fishta was the head of Gjeçov's Franciscan order and the editor of the periodical Hylli i Dritës, in which much of Gjeçov's work was published. These two factors, together with Fishta's evident affection and admiration for Gjeçov, suggest the two men shared a broadly similar outlook. As Gjeçov himself included no comment or introduction to the Kanun, we can take Fishta's essay as an exposition of Gjeçov's, and the wider Franciscan community's, understandings of law and its relationship to society, and also of Gjeçov's motivations in compiling the text. The Foreword placed Gjeçov's text in Savigny's tradition, explicitly located it in a nation-building context and paid tribute to the contribution of his colleague to the nationbuilding effort. In Fishta's essay, we can identify five key arguments, supported by comparative thinking, that offer insights into understandings of the Albanian nation and the process of nationbuilding.

Fishta cited comparative examples from Greece, Persia, Germany and Ireland (I933 [200I], p. xx); by doing so, he placed Albanian folklore on a par with these 'prestigious' examples and illustrated his point with reference to the Albanian poem, 'The Marriage of Halil'. He also compared customary laws and state law (Fishta, I933 [200I], pp. xxiii ff.). He concluded that customary laws arise from the people and are, thus, a true reflection of the national psyche. To be legitimate, state law must be rooted in customary laws; state laws cannot be 'transported' from one place to another, as they lose their inherent connection to the people and, thus, their legitimacy. Customs are, he said, the best way for a legislature to know the people and the power of laws built on customs comes not from fear of punishment, but from the existing influence of those customs. In this argument, Fishta reflected the Germanist strand of the Historical School (see above) and prefigured latertwentieth-century debates about legal transplants (Watson, I974). Seen in the context of the times, this was no mere academic debate; it was a challenge to the Albanian legislators to develop a legal system for the new state rooted in customary laws, which could be seen as legitimate, just, honourable and beneficial to the nation. Further, he believed that, before laws are changed, experts should study the existing laws to determine where changes can be made without altering the essential character of those laws. This was the functional value Fishta saw in Gjeçov's Kanun: it documented the customs of the people and presented them to the (future) legislators.

In claiming that the Kanun was the residue of an ancient, lost, written code (I933 [200I], p. xxvi), Fishta made fleeting but powerful comparisons: he noted that there are (unspecified) similarities with pre-Ottoman legal codes of Rome, Byzantium and Serbia - all of which exist in a written form - suggesting some sort of legal inheritance. As evidence of the existence of historical written law in Albania, he referred to the I468 Statute and Ordinances of the Cathedral Chapter in Drishti, a village located in the modern district of Shkodra in northern Albania (Ahmeti and Lala, I468 [2009]). This echoes an argument Gjeçov may have been making through his comparative references, that Albanian law merits comparison with the great historical legal codes of world, and the Albanians with the people who generated them. Claiming the existence of an ancient 'lost' text also underpinned Gjeçov's text with ideas of ancient authority.

I5 This Foreword is not included in the bilingual edition of the Kanun; references here are to a reprint of the I933 edition. 
In rebutting the claim, made by unspecified accusers, that the Kanun was 'barbarous' (I933 [200I], p. xxvii), through careful comparison, Fishta concluded it was the natural product of a society at a particular stage in its development, and that external circumstances had precluded that society's further development (on his terms, its becoming further 'civilised'). Ironically, given what he went on to say about the 'level' of Ottoman society, he also suggested that Ottoman recognition of the Kanun as the 'civil law' in force in the highlands of Shkodra and Dukagjin was evidence of its general acceptability (I933 [200I], p. xxvii).

By establishing an hierarchy of societies from primitive to advanced, in which the most perfect of cultures was the 'Christian-Occidental culture' (I933 [200r], p. xxix), Fishta was able to locate contemporary Albanian society within his hierarchy. He took it as a universal principle that society and social institutions do, and should, develop along evolutionary lines, subject to internal and external influences, and argued that Albanian society and the Kanun (as both practices and Gjeçov's text) should be understood in that context. Using 'law' (in a broad sense) as his point of reference, this evolutionary model led him to explicit comparative thinking about the current position and condition of the Albanian nation, relative to both historical and contemporary societies. Fishta said the culture of the Albanian nation belonged to the third category in his hierarchy. He said that the Kanun has some laws similar to Roman or Byzantine law, rather than the laws of the 'barbarians' (here, the Ottomans). He stressed the isolation of the Albanian mountain dwellers who had customs based on Christian religious principles and traditions, inherited from an earlier, now extinct, culture.

Last, in locating blood feuding in the context of judicial execution, Fishta acknowledged 'blood' (gjaku), which he explains as 'vendetta', as 'the strongest argument presented by the enemies of Albania, to prove the wildness of the population of our mountains' (I933 [200I], p. xxx). In doing so, he implicitly recognised the comparison being made by 'the enemies of Albania' and the need to counteract such a comparison, which he did with the argument that not all killing is the same. He drew a contrast between a cannibal killing to eat flesh and a judge killing a man as punishment, saying the latter 'is not barbarous'. He said that, in the Albanian mountains, through the 'executive authority of the Kanun and the civil authority of the district (bajrak) of the murderer' (Fishta, I933 [200I], p. xxxi), the house of a murderer would be burned down by his district as punishment, but vengeance was left to the family of the victim. He said that, in killing a murderer, an Albanian does only what he feels necessary to bring about justice; from a psychological point of view, his action 'is a legal action and cannot be called revenge-vendetta' (Fishta, I933 [200I], p. xxxi). He compared such a case with the execution of Louis XVI of France, which was believed to be legal by those who enacted it. In the context of the dichotomy that he presented between 'wild' and 'civilised', this was a powerful comparison with a nation that would have been seen as irrefutably 'civilised'. He further stressed the sense of justice being restored in Albanian communities through 'blood' by noting that, after the killing of the murderer, the two families conciliate and make peace - a pattern that he says was common to 'all the civilised states of Europe after the World War' (Fishta, I933 [200I], p. xxxi). He concluded that blood feuding originated outside indigenous Albanian practices and 'will not always be part of [the nation's] spirit' (Fishta, I933 [200r], p. xxxii); thus, the blood feud should not be taken as evidence 'that the Albanian nation is barbaric and not able to govern independently' (Fishta, I933 [200r], p. xxxii).

From Fishta's comparative thinking, we get the sense that he understood that Gjeçov's Kanun served multiple ideological and pragmatic purposes. His Forward was ideological in that it expressed ideas of Albanian morality and - at least superficially - synthesised diverse ideals and influences from Albanian tribe and church with other historical legal texts and systems. It was also functional, in that it recorded 'authentic' Albanian practices, and could have been used as a 'legal' bridge between pre-state Albanian society and the newly established state. Through the use of comparisons and the creation of a comparative socio-legal taxonomy, Fishta both 
de-particularised Albanian culture - by saying it adhered to an established and universal pattern and particularised it, by emphasising its unique qualities. The latter led him to an explicit conclusion that it would be quite unsuitable to transfer, in whole or in part, a pre-established Western legal model to the Albanian state. Despite the Franciscans' efforts, as the politics of the early twentieth century unfolded, their ideas about the nature of 'law' within a future Albanian state seem to have been crushed by the actions of King Zog (the first monarch of the Albanian state, I928-I939), who established an Albanian state legal system rooted in the legal codes of Italy, Switzerland and France, rather than Albanian customary practices.

\section{Contemporary comparative thinking}

The contemporary relevance of the Kanun is evident in conversations that take place in the cafes of Kosovo. ${ }^{16}$ Since 1999, in the context of post-conflict reconstruction, reform of the legal system has been an enormous undertaking, inherently linked with political reforms taking place in parallel, and has touched or affected many aspects of people's everyday lives. Conversations about such issues rarely make progress before becoming fundamentally comparative. During such conversations, I found that the nature and purpose of the comparisons ranged from general commentary to informal political focus groups, but the common underlying message was that

'something about our law and the way we do law says central things about us which need to be known and understood, if we ourselves are to be known and understood. To ignore these things is to ignore central things about us.'

If pressed to name this sense of 'the way we do law' and make it explicit, for the sake of an outsider, it was encapsulated in the ambiguous concept of 'the Kanun', which, depending on context, could mean the broad sweep of customary practices of the northern Albanians or, more specifically, the text of the same name.

In the small, and very dusty, town of Fushë Kosovo, now almost a suburb of the ever-expanding capital, Prishtina, the former mayor wanted to tell me about the local activities of a national dispute conciliation movement in the I990s, in which he had been a prominent activist. The movement was the Pajtimi i Gjaqeve (Conciliation of Blood Feuds) and, between I990 and I99I, it conciliated over 2,500 intra-Albanian disputes in Kosovo and neighbouring Albanian territories, of which over half were blood feuds (for discussion, see Pritchard, 20I4). In operation, the movement used local-level actors, such as village elders, to conciliate disputes, operating under the auspices of a 'national' council, led by a group of well-known academics and political activists. The point of this movement, he explained, had been to use Albanian traditional practices (which he glossed, albeit reluctantly, as being 'of the Kanun') to solve modern problems, because the Serbian state had failed, and had been increasingly antagonistic towards, Albanians. This movement had been, he said, the only reliable access to justice for Kosovar Albanians. As in conversations with many other informants, the practical and symbolic significance of the movement was expressed in a web of comparisons, including between the non-Albanian state and the Albanian people, unjust state law and national 'law' and justice, authenticity and inauthenticity, and public and private. The whole was embodied in the notion of 'the Kanun' as shorthand for 'the Albanian way of doing law'. Intriguingly, he introduced an additional level of comparison when he explained that these practices, which he had glossed as 'the Kanun', also stood in contrast to 'the Kanun' (as a fixed text) by virtue of the modern ideals embodied in the movement.

I6 The empirical material in this paper draws on fieldwork carried out in Prishtina, Fushë Kosovë and Prizren between July 2010 and October 20I I, supplemented with several shorter visits to the present date. 
Over the course of my fieldwork, it became clear that the themes underpinning my informants' conversations significantly overlapped with the nation-building narratives evident in the earlytwentieth-century comparative thinking in, and about, the Kanun. They were expressing their concerns about the autonomy of the legal community, the distinctness of Albanian culture and the injustice that the Albanian nation was not held in the same esteem on the world stage as other nations that had less history and no sense of indigenous law; and they were making claims about the antiquity, autochthony and resilience of the Albanian 'nation'. This indicated that the nation-building project was ongoing, although now pursued by the 'man on the street', rather than being purely the concern of highly educated intellectuals. Contemporary comparative thinking about Albanian law thus followed a parallel trajectory to that in the writing of Gjeçov and Fishta.

\section{Conclusion}

The emergence of the Albanian nation was a subtle, complex and contested process, but some of the resources used by the nation-builders can be traced to the text of the Kanun and understandings of an 'Albanian' legal tradition, both of which were shaped by comparative thinking.

Gjeçov's Kanun originated in a time when it was clear that there were questions about an Albanian nation and its future, but Albanians were not united in what they wanted and how they could achieve it. It was not the work of powerful leaders, but examining its content allows us glimpses of two individuals who participated in an emerging 'national' narrative about who 'we' are, as the Albanian nation. At a functional level, Gjeçov and Fishta saw the Kanun as contributing to future state institutions, which might be based on the authority of legality (Weber's 'rationallegal authority'). Set in the broader context of nation-building, the Kanun made historical and contemporary claims for, and about, the Albanian people and thus belonged to a growing body of literature that told the Albanians about themselves as a people, in the Albanian language (Elsie, I99I). The comparative thinking in, and about, the Kanun links it to a sense of legal heritage or ancestry. It suggested a people with legal practices and a legal code, which could stand comparison with the world's great examples. It showed Albanians how their folk culture could be thought about and how it could be written, and provided a potential foundation for future development of the Albanian state legal system.

Contemporary Kosovar understandings of Gjeçov's Kanun illustrate some of the tensions facing the new state. The text is readily available in book stores and stalls but, among my informants, was rarely owned or read. Elsie has observed that not having access to, or not having read, an 'important' Albanian text appears, historically, to have been no impediment to passing comment on it - it is the idea of the text itself that is important - which resonates with Goody's comments on 'restricted literacy' in northern Ghana: 'the Book becomes less a means to further enquiry, a step in the accumulation of knowledge, than an end in itself, the timeless depository of all knowledge' (Goody, I968, p. 237). It is important to the Kosovars that the Kanun exists and is known about: within the Kosovar Albanian national community, it is symbolic of an ancient past, the existence of the nation, the national liberation struggle and proof of Albanian scholarship and a literary tradition. Knowledge or recognition of the Kanun by non-Albanians is important to Kosovars as external validation - and thus reinforcement - of these points. For Kosovars, ideas of external validation are intrinsically linked to their understandings of nation and nation-state because of the crucial role played by the Great Powers in the creation of the Albanian state in I9I2, the members of NATO in the 'liberation' of Kosovo in I999 and Kosovo's subsequent slow progress towards full international recognition. Less positive are associations of 'the Kanun' with a backward past and Kosovars are sensitive to the ways in which ideas about the Kanun were used in Serb nationalist propaganda before and during the 1998-1999 war. While the message of 
Albanian nation-builders was that the Kanun was evidence of 'us' as a people and 'our customs', their Serbian equivalents blurred the distinction between text and customary practices, presenting the Kanun as evidence that Kosovars cling to a medieval system of social organisation and order, which renders them incapable of engaging as citizens in a modern state.

Young, urban, educated Kosovars - acutely conscious of being the first generation of new adults in the newly independent state, and broadly supportive and accepting of its institutions - identify 'the Kanun' as being of historical importance to the nation, and yet are keen to dismiss any ideas of its ongoing relevance as a text or a set of customary practices. Some of the practices described in Gjeçov's text are of direct relevance to their everyday lives, particularly those connected to engagement, marriage, inheritance and the inviolability of the home, but they see these as residual, and reject the idea that they are part of a comprehensive framework of right behaviour. In contrast, older, more rural and less-educated Kosovars are more comfortable taking part in, and talking about, customary practices, which they understand still to be a significant part of their lives. Such practices are particularly apparent at times of birth, marriage and death, inheritance, land-ownership and dispute conciliation. While they may summarily describe customary practices collectively as 'the Kanun', they do not relate them to Gjeçov's text, unless pressed, in which case they are usually confident that the practice in question would be found therein.

Some Kosovar legal and social science academics, still conscious of their role as nation-builders, and feeling an obligation to counter a nebulous sense of historical 'anti-Albanian propaganda', continue to mine the text for material to support particular views, including the moral superiority of the Kanun over contemporaneous Islamic law, and proof of links to an Illyrian past. These efforts rarely translate into international peer-reviewed publications, and any outputs seem largely to circulate among a restricted circle of like-minded colleagues. Such research reinforces or extends popular perceptions of the links between the Kanun and a sense of Albanian nationhood.

To return to Parkin's suggestion that the drive to compare is the search for continuity, in Albanians' comparative thinking about their law, the search for continuity still aims to establish national continuity from antiquity to the present day. Both the Kanun and my fieldwork show that comparative thinking by our informants can be nested, complex to identify and integrated in broader patterns of thinking; but it can be an immensely rich source of information about our informants' interpretivist projects, and thereby who they are as a people.

\section{References}

Ahmeti, M. and lala, E. (eds) (I468 [2009]) Statuta et Ordinationes Capituli Ecclesiae Cathedralis Drivastiensis. Tiranë: Ombra.

barleti, M. (I596) The Historie of George Castriot, Surnamed Scanderbeg, King of Albanie, Containing His

Noble Deedes of Armes, and Memorable Victories against the Turks, for the Faith of Christ. London: R. Field for William Ponsonby.

BERLIN, I. (1999) The Roots of Romanticism. London: Pimlico.

BERLIN, I. (2000) Three Critics of the Enlightenment: Vico, Hamann, Herder. London: Pimlico.

Bohannan, P. (I957) Justice and Judgement among the Tiv. London: Oxford University Press.

BRKIĆ, J. (I96I) Moral Concepts in Traditional Serbian Epic Poetry. The Hague: Mouton and Co.

BRock, P. (1976) The Slovak National Awakening. Toronto: University Press.

CHeKrezi, C. (I9I9) Albania Past and Present. New York: The Macmillan Company.

DURHAM, E. (I909 [2000]) High Albania: A Victorian Traveller's Balkan Odyssey. London: Phoenix Press. DURHAM, E. (1928) Some Tribal Origins, Laws and Customs of the Balkans. London: Allen and Unwin.

EFFENDI, W. (I879 [I 999]) The Truth on Albania and the Albanians: Historical and Critical Issues. London:

Centre for Albanian Studies. 
ELSIE, R. (I99I) 'The Scutarine Contribution to the Development of Nineteenth-Century Albanian

Literature', Albanian Catholic Bulletin/Buletini Katolik Shqiptar I 2: 9I-97.

FISHTA, Gj. (I933 [200I]) 'Parathâne' in Sh. Gjeçov Kanuni i Lekë Dukagjinit. Shkodra: Kuvendi.

Fox, L. (I989) 'Introduction' in Sh. Gjeçov Kanuni i Lekë Dukagjinit/The Kanun of Leke Dukagjin.

New York: Gjonlekaj Publishing Company.

FRANKLIN, S. (20I I) 'Mapping the Graphosphere: Cultures of Writing in Early I9th-Century Russia

(and Before)', Kritika I2(3): 53I-560.

GeERTZ, C. (I963) 'The Quest for Modernity in Asia and Africa' in C. Geertz (ed.) Old Societies and New

States. New York: The Free Press of Glencoe.

GELLNER, E. (1983) Nations and Nationalism. Oxford: Blackwell.

GJEÇOv, Sh. (I933 [1989]) Kanuni i Lekë Dukagjinit/The Kanun of Lekë Dukagjin. New York: Gjonlekaj

Publishing Company.

GJEçOv, Sh. (1985) Vepra, 4 vols. Prishtina: Rilindja.

Goody, J. (I968) 'Restricted Literacy in Northern Ghana' in J. Goody (ed.) Literacy in Traditional Societies.

Cambridge: University Press.

GReEnhouse, C. (I988) ‘Courting Difference', Law and Society Review 22: 687-708.

HodGKinson, H. (2004) Scanderbeg. London: Centre for Albanian Studies.

Honoré, A. (I977) 'Real Laws' in P.M.S. Hacker and J. Raz (eds) Law, Morality and Society: Essays in

Honour of H.L.A. Hart. Oxford: Clarendon Press.

JUDAH, T. (I997) The Serbs: History, Myth and the Destruction of Yugoslavia. London: Yale University Press. KARPAT, K. (I982) 'Millets and Nationality: The Roots of the Incongruity of Nation and State in the Post-

Ottoman Era' in B. Braude and B. Lewis (eds) Christians and Jews in the Ottoman Empire: Vol. I The

Central Lands. London: Holmes and Meier Publishing Inc.

KASABA, R. (2008) 'Status of Tribes in the Ottoman Empire' in Joel S. Migdal (ed.) Boundaries and

Belonging: States and Societies in the Struggle to Shape Identities and Local Practices. Cambridge:

Cambridge University Press.

KNIGHT, E.F. (I880) Albania: A Narrative of Recent Travel. London: Sampson Low, Marston, Searle and Rivington.

KÖKSAL, Y. (2006) ‘Centralization and Sedentarization of Tribes in the Ottoman Empire’, Middle Eastern

Studies 42(3): 469-49I.

LEONARD, R. (1907) 'Methods Followed in Germany by the Historical School of Law', Columbia Law

Review 7(8): 573-581.

LIKнovski, A. (2006) Law and Identity in Mandate Palestine. Chapel Hill: University of North Carolina

Press.

MaLcolm, N. (1998) Kosovo: A Short History. London: Macmillan.

Midhat BEY, A. (I903) The Life of Midhat Pasha. London: John Murray.

NJEgosh, P. (1930) The Mountain Wreath of P.P. Nyegosh, Prince-Bishop of Montenegro, I830-I85I.

London: G. Allen \& Unwin Ltd.

olivelle, P. (2006) Manu's Code of Law: A Critical Edition and Translation of the Manava-Dharmasastra.

New Delhi: Oxford University Press.

PARKIN, D. (I987) ‘Comparison as the Search for Continuity’ in L. Holy (ed.) Comparative Anthropology.

Oxford: Basil Blackwell.

PIPA, A. (I978) Albanian Literature: Social Perspectives. Munich: R. Trofenik.

PIRIE, F. (2010) 'Law before Government: Ideology and Aspiration', Oxford Journal of Legal Studies 30(2):

207-228.

PRITCHARD, E. (20I4) 'Albanian Law and Nation-Building in Northern Albania and Kosovo', DPhil thesis, University of Oxford.

ROBERTS, S. (2005) 'After Government? On Representing Law without the State', Modern Law Review 68

(I): I-24. 
RYLE, H. (I909) The Canon of the Old Testament: An Essay on the Gradual Growth and Formation of the Hebrew Canon of Scripture. London: Macmillan and Co. Ltd.

SAVIGNY, F. (I8I4 [I999]) Of the Vocation of Our Age for Legislation and Jurisprudence. Kitchener, Ontario: Batoche Books.

schöpflin, G. (1997) 'The Functions of Myth and a Taxonomy of Myths' in G. Hosking and

G. Schöpflin (eds) Myths and Nationhood. London: Hurst.

schöpflin, G. (2000) ‘Hungary as Kin-State’ in G. Schöpflin (ed.) Nations, Identity, Power. London: Hurst. schwartz, R. (1955) 'Review: The Unwritten Law in Albania by Margaret Hasluck', Stanford Law

Review Stanford Law Review: 56I-57I.

Skendi, S. (I982) 'The Millet System and Its Contribution to the Blurring of Orthodox National

Identity in Albania' in B. Braude and B. Lewis (eds) Christians and Jews in the Ottoman Empire:

Vol. I: The Central Lands. London: Holmes and Meier Publishing Inc. SмITH, A. (I99I) National Identity. London: Penguin.

tarifa, F. (2008) 'Of Time, Honor, and Memory: Oral Law in Albania', Oral Tradition 23(I): 3-I4. тномson, R. (2000) The Lawcode (Datastanagirk') of Mxit'ar Goš. Amsterdam: Rodopi.

todorova, M. (2004) ‘Conversion to Islam as a Trope in Bulgarian Historiography’ in M. Todorova (ed.)

Balkan Identities. London: Hurst.

uZelaC, G. (2010) 'When Is the Nation? Constituent Elements and Processes', Geopolitics 7(2): 33-52. watson, A. (1974) Legal Transplants: An Approach to Comparative Law. Edinburgh: Scottish Academic Press.

watson, A. (1998) Ancient Law and Modern Understanding: At the Edges. London: The University of Georgia Press.

weber, M. (1948) 'The Nation' in H. Gerth and C. Wright Mills (eds) From Max Weber: Essays in Sociology. London: Routledge and Kegan Paul.

williams, K. (I997) 'National Myths in the New Czech Liberalism' in G. Hosking and G. Schöpflin

(eds) Myths and Nationhood. London: Hurst.

Wormald, P. (1999) Legal Culture in the Early Medieval West. London: Hambledon Press. 